\title{
Land Suitability Assessment for Cassava var. Jarak Towo, Using Determinant Factors as the Strategy Fundament in Hilly Area Jatiyoso-Indonesia
}

\author{
Mujiyo $^{1 *}$, Ikhsan Faturahman Suprapto ${ }^{1}$, Aktavia Herawati ${ }^{1}$, Hery Widijanto ${ }^{1}$, Heru Irianto ${ }^{2}$, Erlyna Wida Riptanti ${ }^{2}$ \\ Aulia Qonita ${ }^{2}$ \\ ${ }^{1}$ Department of Soil Science, Faculty of Agriculture, Universitas Sebelas Maret, Surakarta 57126, Indonesia \\ ${ }^{2}$ Department of Agribusiness, Faculty of Agriculture, Universitas Sebelas Maret, Surakarta 57126, Indonesia
}

Corresponding Author Email: mujiyo@staff.uns.ac.id

https://doi.org/10.18280/ijsdp.160614

Received: 23 July 2021

Accepted: 7 September 2021

\section{Keywords:}

cassava, Jarak Towo, land suitability,

determinant factors, management strategy

\begin{abstract}
The increasing demand for various creative food industries requires cassava raw materia supply which has quality and quantity. This research purpose is to identify land suitability, determining the factors, and the strategy of land management for Jarak Towo production in Jatiyoso District. This research using survey method with the land unit based on altitude as observation design which divided into six, namely 400 masl, 600 masl, 800 masl, 1000 masl, 1200 masl, and 1400 masl, and the sampling point is determined by purposive sampling which each land unit has four repetitions and obtain 24 sample points. The land suitability class assessment was carried out by matching the observation data with cassava-modified growth requirements for the Jarak Towo variety. The results in the area were classified into two classes, namely marginally suitable and not suitable. The land suitability determinant factors were temperature, organic carbon, Total-N, and slope. Land units 3 and 4 are land units which land suitability class can increase if these two locations are used as places for planting cassava var. Jarak Towo with the direction of land management strategies that have been given.
\end{abstract}

\section{INTRODUCTION}

Cassava (Manihot esculenta) is a small perennial shrub, usually 2-3 m tall, that produces thickened roots mostly filled with starch and widely grown in tropical and subtropical country [1]. Along with the development of technology and science, cassava is used for various preparations, especially raw materials for the starch-producing food industry [2]. The demand for cassava as a raw material for the food industry sector has increased due to the increasing demand for staple food [3] thus causing the cassava cultivation system to become a more intensive production system [4]. In addition to increasing demand, aspects of the quality and quantity of cassava also need to be considered for the creative food industry sector. Not all varieties of cassava are suitable for creative food raw materials. So far, the most suitable variety is Jarak Towo which has a unique taste, delicious, sweet, and smooth [5]. In addition, Jarak Towo has a higher price compared to other types of cassava. This variety was originally founded in Karanganyar Regency on a dryland mountainous area [5].

Jatiyoso District is one of the producers of cassava in Karanganyar Regency. Cassava is the commodity with the third-highest harvested area after rice and corn. The harvested area of cassava in Jatiyoso District has increased from 610 ha [6] to 662 ha [7]. However, the development of Jarak Towo cassava in Karanganyar Regency including Jatiyoso District is constrained by the limited suitable land for cultivation so that production is not optimal. This variety must be planted at an altitude of $\pm 1,000 \mathrm{~m}$ above sea level, to get high-quality yields
[5]. So it is necessary to increase the productivity of Jarak Towo cassava through land suitability evaluation. Local people in Karanganyar call this cassava "jarak Towo" or "jalak towo" because this variety has flowers and leaves which resembling flowers and seeds of jarak (Jatropha) [5]

Land suitability is the activity of characterizing soils in a certain area for specific land uses [8]. Information on parametric and non-parametric land characteristics collected in land surveys helps in the development of land use plans as well as in estimating the effects of use on the environment [9, 10]. Research on land suitability for cassava commodities refers to land suitability references applicable in Indonesia in the Land Evaluation Technical Guidelines for Agricultural Commodities [8]. The content only presents land suitability criteria for the cassava commodity level in Indonesia, while this study requires land suitability criteria for the Jarak Towo variety. Several studies of cassava var. Jarak Towo has been carried out. Sularti et al. [11] explain the analysis of Sijarwo SMEs farming in Karanganyar Regency which produces various processed cassava var. Jarak Towo. Irianto et al. [5] conclude that it is necessary to implement all key factors to increase the sustainability of cassava var. Jarak Towo development. One of the key factors is land suitability. However, these two studies have not discussed the land suitability of cassava var. Jarak Towo. Therefore, this research is expected to provide innovation related to the arrangement of land suitability class criteria for Jarak Towo cassava.

The aims of this study were: (1) to identify soil and land characteristics for the Jarak Towo cassava in Jatiyoso District, Karanganyar Regency; (2) knowing the land suitability class 
for the Jarak Towo cassava; (3) examine the characteristics of soil and land that are the determining factors that affect land suitability for Jarak Towo cassava and (4) determine the management strategy to increase the land suitability class for Jarak Towo cassava. This research is expected to provide information as a reference to stakeholders or farmers regarding the evaluation of the suitability and potential of the land for the cassava commodity of Jarak Towo in Jatiyoso District, Karanganyar Regency, Central Java.

\section{METHOD}

\subsection{Soil characterization}

The survey was conducted in Jatiyoso District, Karanganyar Regency, Central Java, located at $111^{\circ} 3^{\prime} 0.75^{\prime \prime}-111^{\circ} 11^{\prime} 11.69^{\prime \prime E}$ and $7^{\circ} 41^{\prime} 21.98^{\prime \prime}-7^{\circ} 45^{\prime} 26.30^{\prime \prime S}$ (Figure 1). The research phase consists of (1) pre-survey stage of administrative management to the local government, making a map of land units by observing the field conditions directly, then making a map of the distribution of sample points; (2) the survey stage is carried out with exploration movements to find observation points for soil characteristics and land in the field as well as soil sampling; and (3) the post-survey stage carried out soil sample preparation and sample analysis at the Chemistry and Soil Fertility Laboratory of Soil Science Sebelas Maret University.

The research area of Jatiyoso District is divided into 6 Land Units (LU) with four repetitions determined by purposive sampling to obtain 24 observation points (Figure 2). The materials and tools used in the research are survey tools in the field; GPS, soil drill, shovel, clinometer, stationery, ruler, plastic bag and label for representative soil samples, and laptop. Survey materials; Jatiyoso administration and contour map. Laboratory analysis materials consist of soil samples ready for analysis $(\varnothing 2 \mathrm{~mm}$ and $0.5 \mathrm{~mm})$, chemicals, and laboratory equipment.

\subsection{Data analysis}

The process to determine land suitability requires land evaluation which produces rational data for land use planning [12]. and suitability evaluation includes several aspects such as secondary data collection, primary data acquisition by survey, laboratory analysis, and data analysis [13]. FAO [14] divides land suitability classes into four classes: (1) very suitable class/S1 i.e. land does not have a significant limiting factor to sustainable use, (2) moderately suitable class/S2 i.e. land has limiting factors that affect productivity so that it requires inputs that can still be overcome by farmers, (3) marginal appropriate class/S3 i.e. land has a heavy limiting factor that affects its productivity and requires additional input that is more than land with $\mathrm{S} 2$ class, and (4) unsuitable class/N namely land that is not suitable $(\mathrm{N})$ has a limiting factor that is very difficult to overcome.

Table 1 is the land suitability classification of cassava (Manihot esculenta) which has been modified to suit the Jarak Towo variety on the basis that the Jarak Towo variety produces well at an altitude of 1200 masl [5]. This modified land suitability classification was obtained by observing the soil and land characteristics at 1200 masl as base reference area or S1 class area then averaging every its values of four repetitions (four sample points) for soil and land characteristics value of 1200 masl. The range of suitability values for each soil and land characteristic is adjusted to the suitability of cassava land according to Ritung et al. [8]. The research area of Jatiyoso District has a 950 masl average height with an area of 6,716.4 ha [15] is divided into 6 Land Units (LU) based on altitude as a source of diversity. The land unit is an area with an altitude of $1400 \mathrm{~m}$ (LU 1), $1200 \mathrm{~m}$ (LU 2), $1000 \mathrm{~m}$ (LU 3), $800 \mathrm{~m}$ (LU 4), $600 \mathrm{~m}$ (LU 5), and $400 \mathrm{~m}$ (LU 6) above sea level.

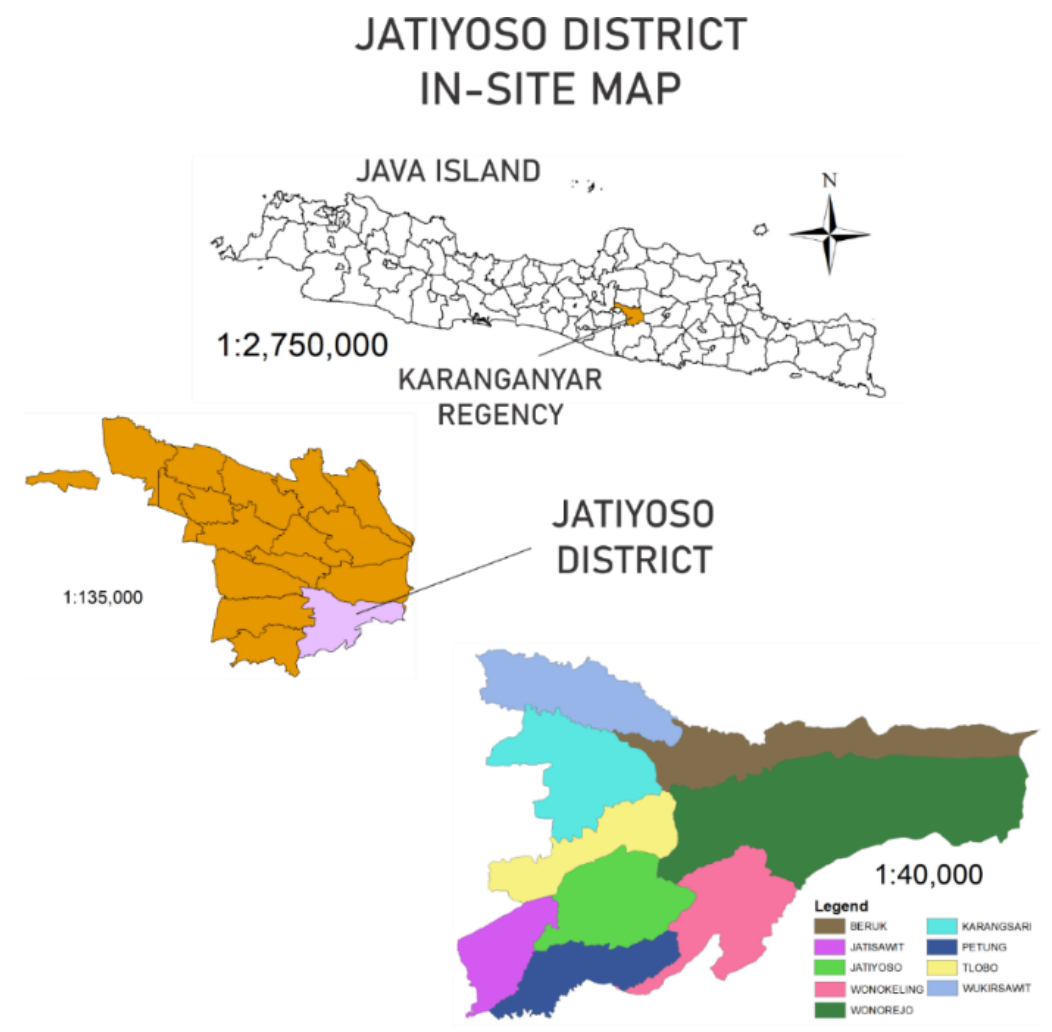

Figure 1. Site map of Jatiyoso District, Karanganyar Regency 


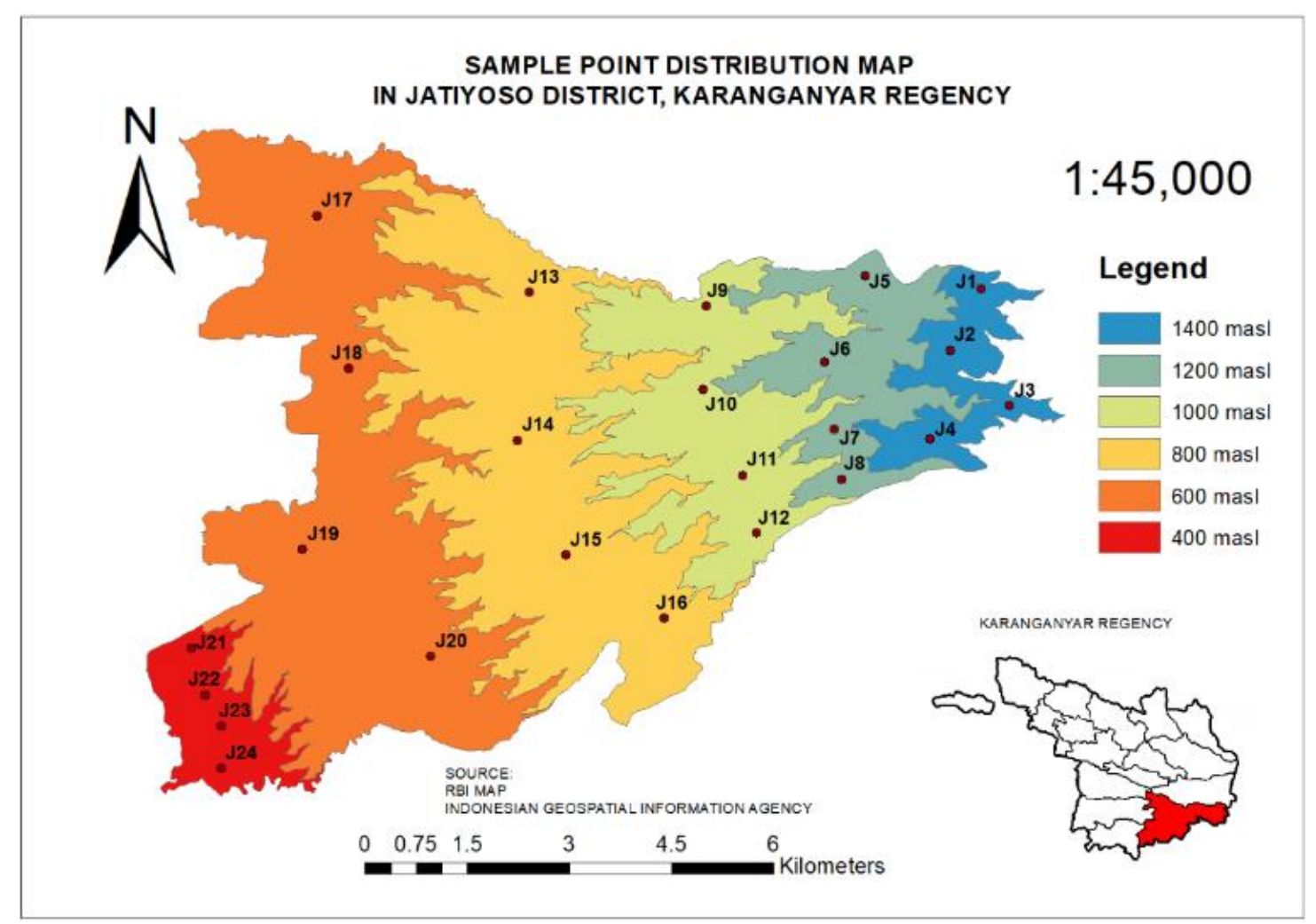

Figure 2. Sample point distribution map in Jatiyoso District, Karanganyar Regency

Table 1. Modified land suitability classification for cassava (Manihot esculenta) adapted from Jarak Towo variety

\begin{tabular}{|c|c|c|c|c|}
\hline $\begin{array}{c}\text { Soil and land } \\
\text { characteristics }\end{array}$ & S1 & S2 & S3 & $\mathbf{N}$ \\
\hline \multicolumn{5}{|l|}{ Temperature (tc) } \\
\hline $\begin{array}{c}\text { Average } \\
\text { temperature }\left({ }^{\circ} \mathrm{C}\right)\end{array}$ & $18-20$ & $20-22$ & $\begin{array}{l}16-18 \\
22-24\end{array}$ & $\begin{array}{l}>24 \\
<16\end{array}$ \\
\hline \multicolumn{5}{|l|}{$\begin{array}{l}\text { Water availability } \\
\text { (wa) }\end{array}$} \\
\hline $\begin{array}{c}\text { Rainfall (mm/year) } \\
\text { Oxygen } \\
\text { availability (oa) }\end{array}$ & $3000-4000$ & $2000-3000$ & $1000-2000$ & $<1000$ \\
\hline Drainage & $\begin{array}{l}\text { well-drained, slightly well-drained, slightly } \\
\text { imperfectly drained }\end{array}$ & $\begin{array}{l}\text { somewhat } \\
\text { excessively drained }\end{array}$ & $\begin{array}{l}\text { imperfectly } \\
\text { drained }\end{array}$ & $\begin{array}{l}\text { very imperfectly drained, } \\
\text { excessively drained }\end{array}$ \\
\hline \multicolumn{5}{|l|}{ Root capacity (rc) } \\
\hline Texture & slightly smooth, moderate, slightly coarse & smooth & very smooth & coarse \\
\hline Coarse material (\%) & $<15$ & $15-35$ & $35-55$ & $>55$ \\
\hline Soil depth $(\mathrm{cm})$ & $>75$ & $50-75$ & $20-50$ & $<20$ \\
\hline \multicolumn{5}{|l|}{$\begin{array}{l}\text { Nutrient retention } \\
(\mathbf{n r})\end{array}$} \\
\hline $\mathrm{CEC}(\mathrm{me} / 100 \mathrm{gr})$ & $>27$ & $16-27$ & $<16$ & - \\
\hline Base saturation $(\%)$ & $>52$ & $<52$ & & \\
\hline $\mathrm{pH} \mathrm{H} 2 \mathrm{O}$ & $5.9-7.0$ & $\begin{array}{l}5.5-5.9 \\
7.0-7.6\end{array}$ & $\begin{array}{l}<5.5 \\
>7.6\end{array}$ & - \\
\hline $\begin{array}{c}\text { Organic-C (\%) } \\
\text { Nutrient } \\
\text { availability (na) }\end{array}$ & $>2.5$ & $2.0-2.5$ & $<2.0$ & - \\
\hline Total-N $(\%)$ & high, medium & very high, low & very low & - \\
\hline $\mathrm{P}_{2} \mathrm{O}_{5}(\mathrm{mg} / 100 \mathrm{~g})$ & medium & low & very low & - \\
\hline $\mathrm{K}_{2} \mathrm{O}(\mathrm{cmol} / \mathrm{kg})$ & medium & low & very low & - \\
\hline $\begin{array}{l}\text { Erosion hazard } \\
(\text { (eh) }\end{array}$ & & & & \\
\hline Slope $(\%)$ & $0-15$ & $15-30$ & $30-45$ & $>45$ \\
\hline $\begin{array}{c}\text { Erosion hazard } \\
\text { Land preparation } \\
\text { (lp) }\end{array}$ & very light, light & medium & heavy & very heavy \\
\hline Rock surface (\%) & $<0.1$ & $0.1-3.0$ & $3.0-25.0$ & $>25.0$ \\
\hline Rock outcrop (\%) & $<0$ & $1-10$ & $10-20$ & $>20$ \\
\hline
\end{tabular}


Land suitability analysis by matching the requirements for plant growth with data from observations of soil and land characteristics. Requirements for plant growth refer to Ritung et al. [8] by modifying that land the Jarak Towo cassava variety has been able to grow and produce well is a land that has a very suitable land suitability class (S1). Altitude for the suitability of cassava is the dominant environmental parameter [16]. The data were statistically tested with the ANOVA test to determine the effect of altitude on land suitability and on land characteristics, if there is a significant effect, then proceed with the DMRT test. The determining factor is obtained by analyzing the correlation between land suitability and soil and land characteristics.

\section{RESULT AND DISCUSSION}

\subsection{Land suitability}

The results showed that the land suitability class for cassava of the Jarak Towo variety in Jatiyoso District only had two classes, namely S3 (marginal fit) in 6,276 hectares and N (not suitable) in 598 hectares (Table 2 and Table 3 ). The value of soil and land characteristics of each land unit (LU) was obtained through an average of 4 sample points per land unit. The values of soil and land characteristics per land unit are then matched with the growing requirements for cassava of the Jarak Towo variety and then presented with an actual land suitability map (Figure 3).

Land Unit 1 (LU 1) is located at an altitude of 1400 masl. The land suitability class in LU 1 is S3 with the limiting factors of temperature, soil depth, oxygen availability, and erosion hazard. LU 2 is located at an altitude of 1200 masl. LU 2 is the base reference area for growing conditions for cassava of the Jarak Towo variety. However, the very steep slope causes the low land suitability class in this land unit to be not suitable $(\mathrm{N})$. LU 3 is located at an altitude of 1000 masl. LU 3 land suitability class is marginal-suitable or S3 with limiting factors of root media, nutrient availability, and erosion hazard.

LU 1 has an average temperature of $17.76^{\circ} \mathrm{C}$. The temperature is influenced by altitude so that the higher an area is above sea level, the temperature will decrease [17]. Cassava tuber yield is affected by altitude [18] and fertilization [19]. The impact of cassava due to low temperatures is inhibited stem cuttings germination, decreased leaf production, and decreased root tuber dry weight [20, 21]. Apart from temperature, the land at LU 1,2, and 3 are steep slopes with values of $30-45 \%$ or even more. A good slope for crop cultivation is less than $28^{\circ}$ or $45 \%$ as an effort to prevent erosion [22]. In addition, agricultural land in mountainous areas besides requiring high nutrient inputs also has a risk of severe erosion which causes problems with water sources in the downstream body [23]. Erosion can be overcome by applying ground cover vegetation [24] and mounds [25].

LU 4 is located at an altitude of 800 masl. The land suitability class at LU 4 is S3 with limiting factors of root media (rc), nutrient retention (nr), and nutrient availability (na). LU 5 is located at an altitude of 600 masl with land suitability class S3 along with the limiting factors of temperature (tc), nutrient retention (nr), and nutrient availability (na). LU 6 is located at an altitude of 400 meters above sea level. LU 6 land suitability classes are temperature (tc), oxygen availability (oa), nutrient retention (nr), and nutrient availability (na).

Table 2. Actual land suitability class for Jarak Towo cassava (LU 1, 2, and 3)

\begin{tabular}{|c|c|c|c|c|c|c|}
\hline \multirow{2}{*}{ Soil and land characteristics } & \multicolumn{2}{|c|}{ LU 1} & \multicolumn{2}{|c|}{ LU 2} & \multicolumn{2}{|c|}{ LU 3} \\
\hline & Score & Class & Score & Class & Score & Class \\
\hline \multicolumn{7}{|l|}{ Temperature (tc) } \\
\hline Average temperature $\left({ }^{\circ} \mathrm{C}\right)$ & 17.76 & S3 & 18.98 & $\mathrm{~S} 1$ & 20.2 & $\mathrm{~S} 2$ \\
\hline \multicolumn{7}{|l|}{ Water availability (wa) } \\
\hline Rainfall (mm/tahun) & $3000-4000$ & S1 & $3000-4000$ & $\mathrm{~S} 1$ & $3000-4000$ & S1 \\
\hline \multicolumn{7}{|l|}{ Oxygen availability (oa) } \\
\hline Drainage & $\begin{array}{l}\text { slightly well- } \\
\text { drained }\end{array}$ & $\mathrm{S} 1$ & $\begin{array}{c}\text { slightly } \\
\text { well-drained }\end{array}$ & $\mathrm{S} 1$ & $\begin{array}{l}\text { slightly } \\
\text { imperfectly } \\
\text { drained }\end{array}$ & $\mathrm{S} 1$ \\
\hline \multicolumn{7}{|l|}{ Root capacity (rc) } \\
\hline Texture & soft & $\mathrm{S} 2$ & soft & $\mathrm{S} 2$ & slightly soft & S1 \\
\hline Coarse material $(\%)$ & $<15$ & S1 & $<15$ & S1 & $<15$ & S1 \\
\hline Soil depth (cm) & 50 & S3 & 80 & $\mathrm{~S} 1$ & 45 & S3 \\
\hline \multicolumn{7}{|l|}{ Nutrient retention (nr) } \\
\hline $\mathrm{CEC}(\mathrm{me} / 100 \mathrm{gr})$ & 16.2 & $\mathrm{~S} 2$ & 17.72 & $\mathrm{~S} 1$ & 20.78 & S1 \\
\hline Base saturation $(\%)$ & 39.74 & $\mathrm{~S} 1$ & 38.62 & S1 & 41.72 & S1 \\
\hline $\mathrm{pH} \mathrm{H} \mathrm{H}_{2} \mathrm{O}$ & 5.98 & $\mathrm{~S} 1$ & 5.94 & S1 & 6.25 & S1 \\
\hline Organic-C (\%) & 2.75 & $\mathrm{~S} 1$ & 2.10 & $\mathrm{~S} 2$ & 2.62 & S1 \\
\hline \multicolumn{7}{|l|}{ Nutrient availability (na) } \\
\hline Total-N (\%) & 0.97 & $\mathrm{~S} 2$ & 0.6 & S1 & 0.33 & S1 \\
\hline $\mathrm{P}_{2} \mathrm{O}_{5}(\mathrm{mg} / 100 \mathrm{~g})$ & 1.99 & $\mathrm{~S} 3$ & 2.05 & S3 & 3.05 & S3 \\
\hline $\mathrm{K}_{2} \mathrm{O}(\mathrm{cmol} / \mathrm{kg})$ & 21.19 & S1 & 20.56 & $\mathrm{~S} 1$ & 21.79 & S1 \\
\hline \multicolumn{7}{|l|}{ Erosion hazard (eh) } \\
\hline Slope (\%) & $30-45$ & $\mathrm{~S} 3$ & $45-65$ & $\mathrm{~N}$ & $30-45 \%$ & S3 \\
\hline Erosion hazard & light & $\mathrm{S} 1$ & light & $\mathrm{S} 1$ & medium & S2 \\
\hline \multicolumn{7}{|l|}{ Land preparation (lp) } \\
\hline Rock surface $(\%)$ & $<0.1$ & $\mathrm{~S} 1$ & $<0.1$ & $\mathrm{~S} 1$ & $<0.1$ & S1 \\
\hline Rock outcrop (\%) & 0 & S1 & 0 & S1 & 0 & S1 \\
\hline Actual land suitability class & \multicolumn{2}{|c|}{ S3 (tc, rc, na, eh) } & \multicolumn{2}{|c|}{$\mathbf{N}(\mathbf{e h})$} & \multicolumn{2}{|c|}{ S3 (rc, na, eh) } \\
\hline
\end{tabular}


Table 3. Actual land suitability class for Jarak Towo cassava (LU 4, 5, and 6)

\begin{tabular}{|c|c|c|c|c|c|c|}
\hline \multirow{2}{*}{ Soil and land characteristics } & \multicolumn{2}{|c|}{ LU 4} & \multicolumn{2}{|c|}{ LU 5} & \multicolumn{2}{|c|}{ LU 6} \\
\hline & Score & Class & Score & Class & Score & Class \\
\hline \multicolumn{7}{|l|}{ Temperature (tc) } \\
\hline Average temperature $\left({ }^{\circ} \mathrm{C}\right)$ & 21.42 & $\mathrm{~S} 2$ & 22.64 & S3 & 23.86 & S3 \\
\hline \multicolumn{7}{|l|}{ Water availability (wa) } \\
\hline Rainfall (mm/tahun) & $3000-4000$ & S1 & $3000-4000$ & S1 & $2500-3000$ & $\mathrm{~S} 2$ \\
\hline \multicolumn{7}{|l|}{ Oxygen availability (oa) } \\
\hline Drainage & $\begin{array}{l}\text { slightly } \\
\text { imperfectly } \\
\text { drained }\end{array}$ & $\mathrm{S} 1$ & $\begin{array}{l}\text { slightly } \\
\text { imperfectly } \\
\text { drained }\end{array}$ & S1 & $\begin{array}{l}\text { imperfectly } \\
\text { drained }\end{array}$ & S3 \\
\hline \multicolumn{7}{|l|}{ Root capacity (rc) } \\
\hline Texture & slightly coarse & S1 & moderate & S1 & slightly soft & S1 \\
\hline Coarse material (\%) & $<15$ & S1 & $15-35$ & S2 & $15-35$ & S2 \\
\hline Soil depth $(\mathrm{cm})$ & 20 & S3 & 50 & S2 & 80 & S1 \\
\hline \multicolumn{7}{|l|}{ Nutrient retention (nr) } \\
\hline $\mathrm{CEC}(\mathrm{me} / 100 \mathrm{gr})$ & 22.02 & S1 & 22.37 & S1 & 21.93 & S1 \\
\hline Base saturation (\%) & 40.99 & S1 & 39.56 & S1 & 40.52 & S1 \\
\hline $\mathrm{pH} \mathrm{H}_{2} \mathrm{O}$ & 6.1 & S1 & 5.92 & S1 & 6.06 & S1 \\
\hline Organic-C (\%) & 1.71 & S3 & 1.76 & S3 & 1.09 & S3 \\
\hline \multicolumn{7}{|l|}{ Nutrient availability (na) } \\
\hline Total-N (\%) & 0.21 & $\mathrm{~S} 2$ & 0.27 & $\mathrm{~S} 2$ & 0.25 & $\mathrm{~S} 2$ \\
\hline $\mathrm{P}_{2} \mathrm{O}_{5}(\mathrm{mg} / 100 \mathrm{~g})$ & 2.24 & S3 & 2 & S3 & 2.1 & S3 \\
\hline $\mathrm{K}_{2} \mathrm{O}(\mathrm{cmol} / \mathrm{kg})$ & 26.11 & $\mathrm{~S} 1$ & 20.91 & S1 & 29.73 & S1 \\
\hline \multicolumn{7}{|l|}{ Erosion hazard (eh) } \\
\hline Slope $(\%)$ & $15-30$ & $\mathrm{~S} 2$ & $3-8$ & S1 & $3-8$ & S1 \\
\hline Erosion hazard & medium & $\mathrm{S} 2$ & medium & S2 & medium & S2 \\
\hline \multicolumn{7}{|l|}{ Land preparation (lp) } \\
\hline Rock surface $(\%)$ & $<0.1$ & $\mathrm{~S} 1$ & $<0.1$ & S1 & $<0.1$ & S1 \\
\hline Rock outcrop (\%) & 0 & $\mathrm{~S} 1$ & 0 & S1 & 0 & S1 \\
\hline Actual land suitability class & \multicolumn{2}{|c|}{ S3 (rc, nr, na) } & \multicolumn{2}{|c|}{ S3 (tc, nr, na) } & \multicolumn{2}{|c|}{ S3 (tc, oa, nr, na ) } \\
\hline
\end{tabular}

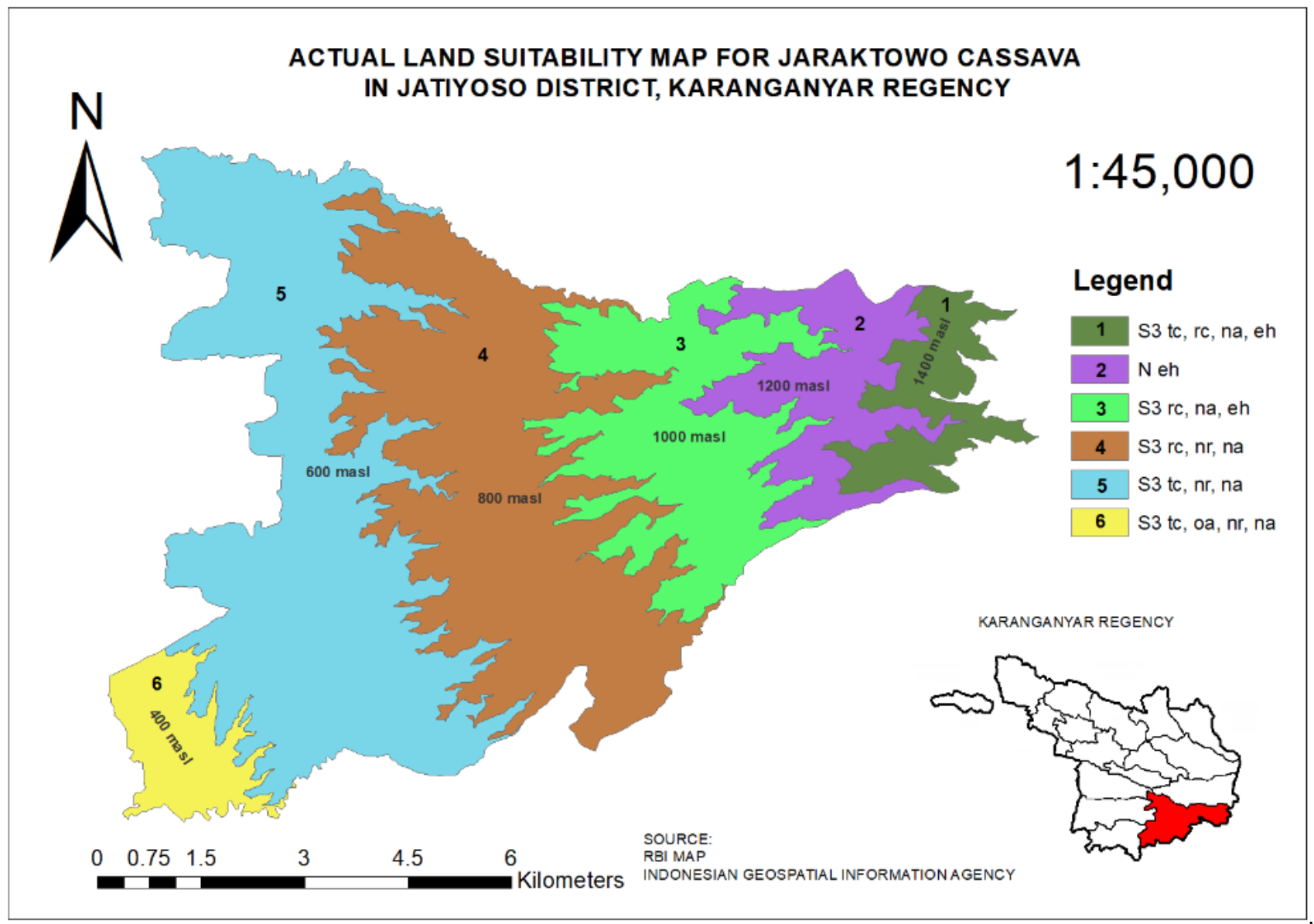

Figure 3. Actual land suitability map for Jarak Towo cassava 
Table 4. Land suitability determining factors of Jarak Towo cassava

\begin{tabular}{|c|c|c|c|c|c|c|c|c|c|c|c|c|c|c|c|c|c|c|}
\hline & $\mathbf{L S}$ & Temp & RF & Drain & Text. & CM & SD & CEC & BS & pH & OC & TN & $\mathbf{P}_{2} \mathrm{O}_{5}$ & $\mathrm{~K}_{2} \mathrm{O}$ & EH & Sole & $\mathbf{R S}$ & RO. \\
\hline \multicolumn{19}{|l|}{ Land suitability } \\
\hline Temperature & $.474^{*}$ & & & & & & & & & & & & & & & & & \\
\hline Rainfall & -.174 & $-.416^{*}$ & & & & & & & & & & & & & & & & \\
\hline Drainage & -.111 & -.164 & .174 & & & & & & & & & & & & & & & \\
\hline Texture & .265 & $.497^{*}$ & -.193 & -.159 & & & & & & & & & & & & & & \\
\hline Coarse material & -.063 & -.279 & -.165 & -.063 & -.111 & & & & & & & & & & & & & \\
\hline Soil depth & -.076 & $-.472^{*}$ & .122 & .108 & -.400 & .222 & & & & & & & & & & & & \\
\hline CEC & .196 & $.475^{*}$ & -.292 & .218 & .046 & -.044 & -.391 & & & & & & & & & & & \\
\hline $\mathrm{BS}$ & .147 & .087 & .064 & -.115 & .330 & -.251 & -.194 & -.079 & & & & & & & & & & \\
\hline $\mathrm{pH}$ & .100 & .030 & .005 & -.134 & .373 & -.250 & -.309 & .027 & $.892^{* *}$ & & & & & & & & & \\
\hline Organic-C & $-.408^{*}$ & $-.777^{* *}$ & .343 & .170 & $-.469^{*}$ & .346 & .345 & -.247 & -.049 & .007 & & & & & & & & \\
\hline Total-N & $-.438^{*}$ & $-.805^{* *}$ & .215 & .022 & $\begin{array}{c}-.648^{*} \\
*\end{array}$ & .341 & $.485^{*}$ & $-.414^{*}$ & -.272 & -.271 & $.645^{* *}$ & & & & & & & \\
\hline $\mathrm{P}_{2} \mathrm{O}_{5}$ & .052 & .002 & -.046 & .167 & .294 & -.195 & -.400 & .118 & .041 & .284 & .148 & -.209 & & & & & & \\
\hline $\mathrm{K}_{2} \mathrm{O}$ & .178 & .363 & $-.411^{*}$ & -.364 & .139 & -.132 & -.080 & .184 & -.078 & .064 & -.317 & -.189 & .149 & & & & & \\
\hline Erosion hazard & .098 & -.352 & .051 & -.098 & -.170 & -.130 & .236 & -.131 & .006 & .054 & .119 & .337 & .252 & .146 & & & & \\
\hline Slope & $-.723^{* *}$ & $-.751^{* *}$ & .355 & .241 & -.247 & .196 & .333 & -.199 & -.045 & .023 & $.616^{* *}$ & $.484^{*}$ & .122 & -.309 & .224 & & & \\
\hline Rock surface & .200 & -.276 & -.104 & .067 & -.222 & $.722^{* *}$ & .259 & -.025 & -.194 & -.247 & .322 & .247 & -.107 & -.285 & .059 & .197 & & \\
\hline Rock outcrop & .364 & .249 & -.114 & -.218 & .312 & .290 & .172 & .064 & -.229 & -.214 & -.038 & -.117 & .046 & .089 & -.064 & -.129 & .393 & \\
\hline
\end{tabular}

The low Organic-C at $400-800$ masl is due to the lower altitude compared to an altitude of 1000-1400 masl [26]. High organic matter content not only provides nitrogen requirements for plants but also increases the water retention capacity of the soil and creates a favorable physical, chemical, and biological environment [27]. Soil organic matter has a very influential effect on the activity and diversity of microorganisms [28-30] involved in the degradation process of soil pollutants [31].

\subsection{Land suitability determinant factors}

The determinant factors of land suitability of the Jarak Towo cassava variety were obtained through a correlation test between several soils and land characteristics and the land suitability class of the Jarak Towo variety. Table 4 shows the correlation value between the observed soil and land characteristics and the land suitability class. The R-value is a Pearson value that indicates the strength and weakness of the correlation between soil and land characteristics and land suitability class.

\subsubsection{Temperature}

Based on Table 4, the correlation test shows that temperature is significantly positively correlated with land suitability class $(\mathrm{R}=0.474 *$; Sig. 2-tailed $=0.019)$ and is a determining factor. Temperature plays a role in germination [32], leaf shape or size, and root dry weight [33]. Cassava can grow with an average annual temperature of $25-29^{\circ} \mathrm{C}$ but cassava can also grow at a temperature of $16-30^{\circ} \mathrm{C}$ or be tolerant to these temperatures [34].

\subsubsection{Nutrient retention}

Nutrient retention consisted of soil CEC, base saturation, $\mathrm{pH}$, and organic-C (OC). The results of the observations showed that land units 4, 5 and 6 had limiting factors of OC. The correlation test showed that there was a significant negative correlation between $\mathrm{OC}$ and land suitability class ( $\mathrm{R}$ $=-0.408^{*}$; Sig. 2-tailed $=0.048$ ) so that $\mathrm{OC}$ was a determining factor for land suitability class for Jarak Towo cassava variety. The value of the low OC is found at altitudes of 800,600 , and 400 meters above sea level with an average temperature between $22-24^{\circ} \mathrm{C}$. This shows temperature conditions significantly negatively correlated with OC. The higher the temperature in the study area, the lower the OC content of the soil. Following the research of Dan et al. [35] that altitude has a significant effect on the rate of decomposition of soil organic matter. The highest decomposition is in areas with an altitude of 1700-2000 masl, while the lowest is in areas with an altitude of 1100-1700. High temperatures can increase the rate of degradation of organic matter. On the other hand, soils in colder climates will contain more organic matter because the rate of decomposition is slower [36].

\subsubsection{Nutrient availability}

Nutrient availability consists of the characteristics of soil Total-N (TN), $\mathrm{P}_{2} \mathrm{O}_{5}$, and $\mathrm{K}_{2} \mathrm{O}$. The entire unit of land has a very low $\mathrm{P}_{2} \mathrm{O}_{5}$. This causes available nutrients to be a limiting factor for all land units for the growth of Jarak Towo cassava. A correlation test was conducted between the characteristics of nutrient availability (na) and land suitability class. TN is a soil and land characteristic that has a significant negative correlation with land suitability class so that $\mathrm{TN}$ is a determining factor for land suitability class for cassava of the Jarak Towo variety $(R=-0.438 *$; Sig. 2-tailed $=0.032)$. TN is one of the characteristics of soil and land that has a high land suitability value or is very suitable if the value is optimal. Excess $\mathrm{N}$ in the soil can have an impact on plant growth. The problems faced by plants in general when dealing with excess $\mathrm{N}$ are that plants are easy to fall [37] and experience ammonia toxicity [38]. Symptoms caused by cassava that have excess N, namely leaf color become dark green, succulent, and inhibits the absorption of $\mathrm{P}$ and $\mathrm{Ca}[39]$.

\subsubsection{Erosion hazard}

The limiting factor for erosion hazard (eh) is found in three land units, namely land units 1,2 , and 3 . The characteristics of soil and land that have an impact on the determinants of land suitability for cassava of the Jarak Towo variety are the percentage of slope. Land unit 2 has a very high average slope percentage level of $45-65 \%$ so that land unit 2 is classified as land suitability class $\mathrm{N}$ (not suitable). The slope greatly determines the amount of erosion that occurs [40]. The slope affects the depth of the soil and soil profile thickness. Rezaei et al. [41] explained that some areas with a low percentage of slopes (toe slope areas) have quite deep soil due to deposits obtained from areas with high slopes (upper slope), but there are also steep slope areas with quite deep soil depth. The correlation test showed that the slope was significantly negatively correlated with land suitability class $(R=-0.723 * *$; 
Sig. 2-tailed $=0.000$ ). Thus, the steeper or greater the percentage of the slope, the worse the land suitability value for cassava varieties of Jarak Towo. Everest et al. [42] using the Analytical Hierarchy Process (AHP) scoring method where slopes with a percentage of $0-2 \%$ get a score of 10 , while a slope above $30 \%$ gets a 1 score. So, it concludes that the flatter the area, the higher the score, and vice versa.

\subsection{Land management strategies}

Figure 4 describes strategies to improve or manage each land unit based on the determining factors for cassava of the Jarak Towo variety. However, some soil and land characteristics such as temperature which is affected by altitude cannot be improved. Land improvement has to consider the level of management efficiency required both in terms of cost and energy [43].

Land units 1, 2, and 3 are land units that have a slope determining factor. Efforts to repair that can be done are the construction of the terrace or planting a cover crop. The terrace is a soil and water conservation building that has the function of reducing the length of the slope and retaining water. Other efforts such as planting cover crops can prevent soil erosion and runoff [44].

Land units 4, 5, and 6 have the determinants of Organic-C and Total-N. The three land units need to be managed by adding organic matter. Soil organic matter is a heterogeneous and dynamic soil component that can increase crop productivity and maintain a sustainable agricultural system [45]. The addition of organic matter can increase the availability of nitrogen [46], phosphorus, and potassium [47] in the soil. The addition of organic matter can increase $\mathrm{pH}$ and organic-C in cassava cultivation land [48]. Prasetyo [49] reported that the application of a combination of $300 \mathrm{~kg} / \mathrm{ha}$ of urea with 5 tons/ha of manure was also able to stimulate cassava roots with an increase of $214.58 \%$ compared to control. Based on the results, land units 3 and 4 are land units which land suitability class can increase if these two locations are used as places for planting cassava var. Jarak Towo with the direction of land management strategies that have been given.

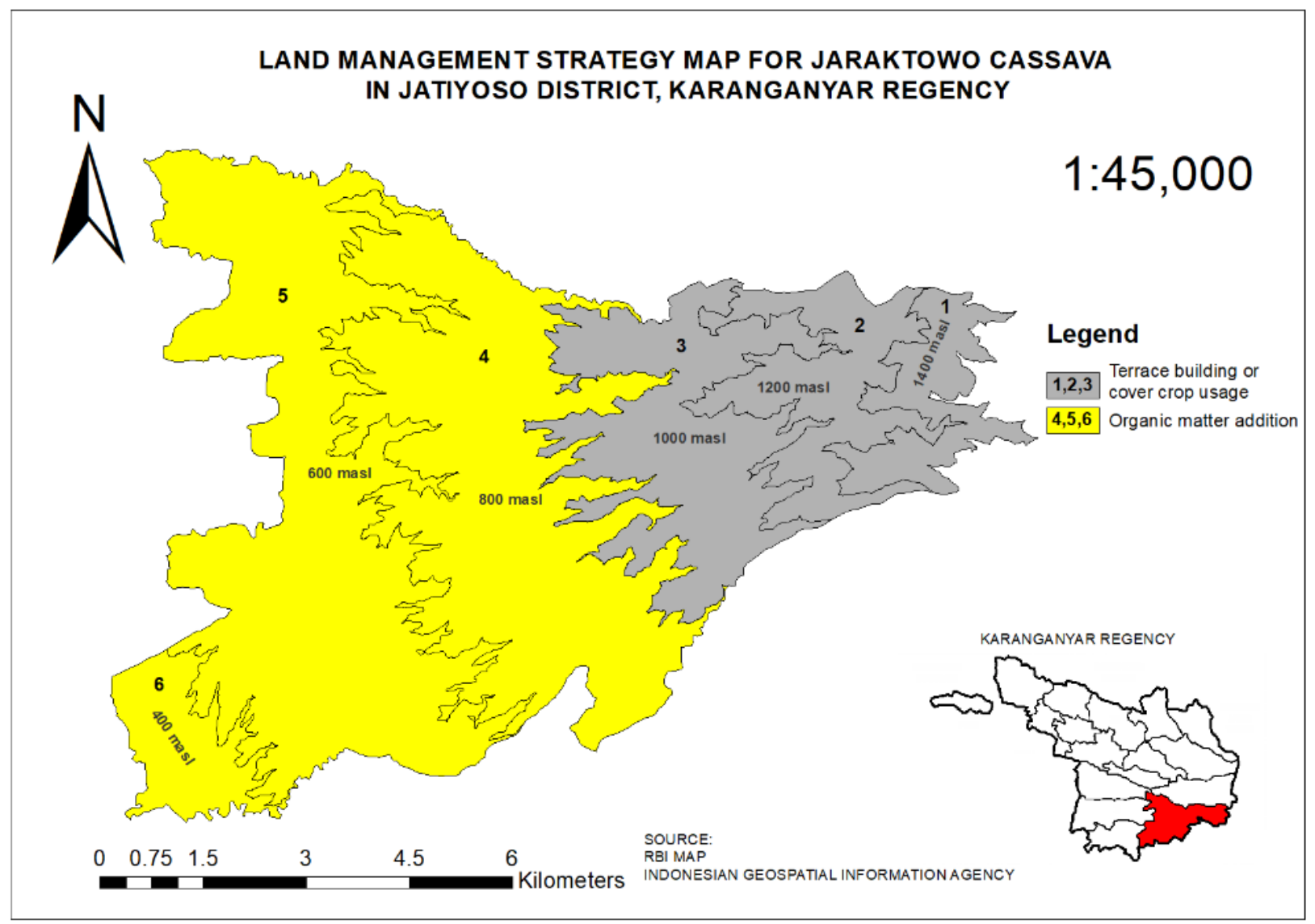

Figure 4. Land management strategy map for Jarak Towo Cassava

\section{CONCLUSIONS}

Soil and land characteristics in Jatiyoso District are very diverse in each land unit with land suitability class for cassava of the Jarak Towo variety consisting of marginal suitable (S3) and not suitable $(\mathrm{N})$. The altitude of the area has a significant effect on land suitability class indirectly through the soil and land characteristics such as temperature, Organic-C, Total-N, and slope which then becomes the determining factor for land suitability class spread over the six LU such as temperature and slope in LU 1, 2, and 3 so that land management strategies need to be carried out such as terrace development or planting cover crop, while the determinants of C-organic and N-total are found in LU 4, 5, and 6 which then need to be carried out land management strategies such as adding organic materials. LU 3 and 4 are the land units which has less determinant factors and cassava var. Jarak Towo plantation could be carried out. Researchers suggest that research on various themes related to cassava of the Jarak Towo variety is carried out again in the future so that cassava of the Jarak Towo variety can compete with other creative food industry commodities. 


\section{ACKNOWLEDGMENT}

We are thanks to the Soil Science Department, Agribusiness Department, Community Research and Development Institute of Sebelas Maret University Surakarta, Novi Rahmawati Sutopo, and Tiara Hardian for their support of this research.

\section{REFERENCES}

[1] Howeler, R.H. (2014). Sustainable Soil and Crop Management of Cassava in Asia: A Reference Manual. Cali: Centro Internacional de Agricultura Tropical. https://core.ac.uk/download/pdf/132662687.pdf.

[2] Aristizábal, J., García, J.A., Ospina, B. (2017). Refined cassava flour in bread making: A review. Ing. e Investig., 37(1): 25-33. https://doi.org/10.15446/ing.investig.v37n1.57306

[3] Kefas, J., Zemba, A.A., Hamza, A. (2016). Land suitability analysis for decision-making in cassava (Manihot Spp.) cultivation in southern part of Adamawa State, Nigeria. Glob. J. Agric. Sci., 16(1). https://doi.org/10.4314/gjass.v16i1.1

[4] Food and Agriculture Organization (FAO). (2013). A 21 st century crop. In: Save and grow: Cassava. A guide to sustainable production intensification. FAO, Rome, pp. $1-18$. https://www.fao.org/ag/save-andgrow/cassava/en/1/index.html.

[5] Irianto, H., Mujiyo, M., Qonita, A., Sulistyo, A., Riptanti, E.W. (2020). The development of jarak towo cassava as a high economical raw material in sustainability-based food processing industry. AIMS Agriculture and Food, 6(1): 125-141. https://doi.org/10.3934/agrfood.2021008

[6] Karanganyar Regency Central Bureau of Statistics. (2019). Jatiyoso District in Figure 2019. Karanganyar Regency Central Bureau of Statistics, Karanganyar, p. 55. https://karanganyarkab.bps.go.id/publication/download. html?nrbvfeve=MDBjN2E1MWI0ZmQzNmU4YTRjM TU5ZTAy\&xzmn=aHR0cHM6Ly9rYXJhbmdhbnlhcmt hYi5icHMuZ28uaWQvcHVibGljYXRpb24vMjAxOS8 wOS8yNi8wMGM3YTUxYjRmZDM2ZThhNGMxNT1 IMDIva2VjYW1hdGFuLWphdG15b3NvLWRhbGFtL WFuZ2thLTIwMTkuaHRtbA\%3D\%3D\&twoadfnoarfe auf=MjAyMS0xMC0yOCAxNTozODowNQ\%3D\%3D.

[7] Karanganyar Regency Central Bureau of Statistics. (2020). Jatiyoso District in Figure 2020. Karanganyar Regency Central Bureau of Statistics, Karanganyar, pp. 65.

https://karanganyarkab.bps.go.id/publication/download. html?nrbvfeve=MjdmMGQxY2Q2YzBjYjhlZWNkZDk xN2Vh\&xzmn=aHR0cHM6Ly9rYXJhbmdhbnlhcmthY i5icHMuZ28uaWQvcHVibGljYXRpb24vMjAyMC8w OS8yOC8yN2YwZDFjZDZjMGNiOGVIY2RkOTE3Z WEva2VjYW1hdGFuLWphdGl5b3NvLWRhbGFtLWF uZ2thLTIwMjAuaHRtbA\%3D\%3D\&twoadfnoarfeauf= MjAyMS0xMC0yOCAxNTo0MDowNA\%3D\%3D.

[8] Ritung, S., Nugroho, K., Mulyani, A., Suryani, E. (2011). Technical Guidelines of Land Evaluation for Agricultural Commodities (Revised Edition). Bogor: Center for Research and Development of Agricultural Land Resources, Agricultural Research and Development Agency. https://bbsdlp.litbang.pertanian.go.id/ind/index.php?opti on=com_phocadownload $\&$ view=category $\&$ download= 20:evaluasi-lahan-untuk-komoditas-

pertanian\&id=7:petunjuk-teknis\&Itemid $=451$.

[9] Rossiter, D.G. (1990). ALES: a framework for land evaluation using a microcomputer. Soil Use Manag., 6(1): 7-20. 2743.1990.tb00790.x

https://doi.org/10.1111/j.1475-

[10] Diallo, M.D., Wood, S.A., Diallo, A., et al. (2016). Soil suitability for the production of rice, groundnut, and cassava in the peri-urban Niayes zone, Senegal. Soil Tillage Res., 155: 412-420. https://doi.org/10.1016/j.still.2015.09.009

[11] Sularti, S., Harisudin, M., Qonita, A. (2021). Sijarwo SMEs processed cassava business, Wonorejo Village, Jatiyoso District, Karanganyar Regency. J. Agrista., 9(1): 110-121. Available: https://jurnal.uns.ac.id/agrista/article/view/50803/31397

[12] Herzberg, R., Pham, T.G., Kappas, M., Wyss, D., Tran, C.T.M. (2019). Multi-criteria decision analysis for the land evaluation of potential agricultural land use types in a hilly area of Central Vietnam. Land, 8(6). https://doi.org/10.3390/land8060090

[13] Abah, R.C., Petja, B.M. (2016). Crop suitability mapping for rice, cassava, and yam in north central Nigeria. J. $\begin{array}{llll}\text { Agric. } & \text { Sci., } & \text { 9(1): }\end{array}$ https://doi.org/10.5539/jas.v9n1p96

[14] FAO. (1976). A Framework for Land Evaluation. FAO, Rome.

https://www.fao.org/3/x5310e/x5310e03.htm\#2.7\%20la nd\%20suitability\%20and\%20land\%20capability.

[15] Karanganyar Regency Central Bureau of Statistics. (2020). Karanganyar Regency in Figure 2020. Karanganyar Regency Central Bureau of Statistics, Karanganyar, p. https://karanganyarkab.bps.go.id/publication/download. html?nrbvfeve=YTFhNGE5ZDMwYTZjOTJkMTQ5Zj VhMmE2\&xzmn=aHR0cHM6Ly9rYXJhbmdhbnlhcmt hYi5icHMuZ28uaWQvcHVibGljYXRpb24vMjAyMC8 wNC8yNy9hMWE0YTlkMzBhNmM5MmQxNDlmN WEyYTYva2FidXBhdGVuLWthcmFuZ2FueWFyLW RhbGFtLWFuZ2thLTIwMjAuaHRtbA\%3D\%3D\&twoa dfnoarfeauf=MjAyMS0xMC0yOCAxOTowNzozNw\% 3D\%3D.

[16] Heumann, B.W., Walsh, S.J., McDaniel, P.M. (2011). Assessing the application of a geographic presence-only model for land suitability mapping. Ecol. Inform., 6(5): 257-269. https://doi.org/10.1016/j.ecoinf.2011.04.004

[17] Linacre, E. (1982). The effect of altitude on the daily range of temperature. J. Climatol., 2(4): 375-382. https://doi.org/10.1002/joc.3370020407

[18] Noerwijati, K., Budiono, R. (2015). Yield and yield components evaluation of cassava (manihot esculenta crantz) clones in different altitudes. Energy Procedia, 65: 155-161. https://doi.org/10.1016/j.egypro.2015.01.050

[19] Fernandes, A.M., Gazola, B., Nunes, J.G.D.S., Garcia, E.L., Leonel, M. (2017). Yield and nutritional requirements of cassava in response to potassium fertilizer in the second cycle. J. Plant Nutr., 40(20): 27852796. https://doi.org/10.1080/01904167.2017.1382520

[20] Alves, A.A.C. (2002). Cassava botany and physiology. Cassava: Biology, Production and Utilization, R. J. Hillocks and J. M. Thresh, Eds. Wallingford: CABI Publishing, 67-89.

[21] An, D., Yang, J., Zhang, P. (2012). Transcriptome profiling of low temperature-treated cassava apical 
shoots showed dynamic responses of tropical plant to cold stress. BMC Genomics, 13(1). https://doi.org/10.1186/1471-2164-13-64

[22] Zhang, Z., Sheng, L., Yang, J., Chen, X.A., Kong, L., Wagan, B. (2015). Effects of land use and slope gradient on soil erosion in a red soil hilly watershed of southern China. $\quad$ Sustain., 7(10): 14309-14325. https://doi.org/10.3390/su71014309

[23] Lee, G.J., Lee, J.T., Ryu, J.S., Hwang, S.W., Yang, J.E., Joo, J.H., Jung, Y.S. (2010). Status and soil management problems of highland agriculture of the main mountainous region in the South Korea. World, 154-157.

[24] Liu, R., Pan, Y.F., Bao, H., Liang, S.C., Jiang, Y., Tu, H.R., Nong, J.L., Huang, W.Q. (2020). Variations in soil physico-chemical properties along slope position gradient in secondary vegetation of the hilly region, Guilin, southwest China. Sustain., 12(4): 1-16. https://doi.org/10.3390/su12041303

[25] Banuwa, I.S., Hidayat, K.F., Zulkarnain, I., Sanjaya, P., Afandi, Rahmat, A. (2020). Soil loss and cassava yield under ridge tillage in humid tropical climate of sumatera, Indonesia. Int. J. GEOMATE, 18(67): 1-7. https://doi.org/10.21660/2020.67.78211

[26] Bangroo, S.A., Najar, G.R., Rasool, A. (2017). Effect of altitude and aspect on soil organic carbon and nitrogen stocks in the Himalayan Mawer Forest Range. Catena, 158: 63-68. https://doi.org/10.1016/j.catena.2017.06.017

[27] Khaki, B.D., Honarjoo, N., Davatgar, N., Jalalian, A., Golsefidi, H.T. (2017). Assessment of two soil fertility indexes to evaluate paddy fields for rice cultivation. Sustain., 9(8): 1-13. https://doi.org/10.3390/su9081299

[28] Mujiyo, M., Sunarminto, B.H., Hanudin, E., Widada, J., Syamsiah, J. (2017). Methane production potential of soil profile in organic paddy field. Soil Water Res., 12(4): 212-219.

[29] Mujiyo, Sunarminto, B.H., Hanudin, E., Widada, J., Syamsiah, J. (2018). The effect of organic paddy field system to soil properties. In IOP Conference Series: Earth and Environmental Science, 122: 012023.

[30] Supriyadi, Pratiwi, M.K., Minardi, S., Prastiyaningsih, N.L. (2020). Carbon organic content under organic and conventional paddy field and its effect on biological activities (a case study in Pati Regency, Indonesia). Caraka Tani J. Sustain. Agric., 35(1): 108-116. http://dx.doi.org/10.20961/carakatani.v35i1.34630

[31] Neumann, D., Heuer, A., Hemkemeyer, M., Martens, R., Tebbe, C.C. (2014). Importance of soil organic matter for the diversity of microorganisms involved in the degradation of organic pollutants. ISME J., 8(6): 12891300. https://doi.org/10.1038/ismej.2013.233

[32] Keating, B., Everson, J. (1979). Effect of soil temperature on sprouting and sprout. F. Crop. Res., 2: 241-251. https://doi.org/10.1016/0378-4290(79)90026-1

[33] Irikura, Y., Cock, J.H., Kawano, K. (1979). The physiological basis of genotype-temperature interactions in cassava. F. Crop. Res., 2: 227-239. https://doi.org/10.1016/0378-4290(79)90025-X

[34] Yahaya, T.I., Samsideen, O., Tsado, E.K. (2016). Assessment of the relationship between increase in height of cassava growth rate and agro-climatic parameters in Ilorin area of Kwara state, Nigeria. Adv. Nat. Sci., 9(2): 1-7. https://doi.org/10.3968/8486

[35] Wang, D., He, N.P., Wang, Q., Lü, Y.L., Wang, Q.F., Xu, Z.W., Zhu, J.X. (2016). Effects of temperature and moisture on soil organic matter decomposition along elevation gradients on the Changbai Mountains, Northeast China. Pedosphere, 26(3): 399-407. https://doi.org/10.1016/S1002-0160(15)60052-2

[36] Nurlaeny, N. (2015). Soil Organic Matter and Dynamics of Plant Nutrient Availability. Unpad Press: Bandung. http://pustaka.unpad.ac.id/wpcontent/uploads/2015/12/Buku-Bahan-Organik-TanahDan-Dinamika-Ketersediaan-Unsur-Hara-Tanaman.pdf.

[37] Nurhidayati. (2017). Soil Fertility and Health: An Introduction to Soil Quality Assessment Towards Sustainable Agriculture. Malang: Intimedia.

[38] Roy, R.N., Finck, A., Blair, G.J., Tandon, H.I.S. (2006). Plant Nutrition for Food Security: A Guide for Integrated Nutrient Management. https://www.fao.org/fileadmin/templates/soilbiodiversit y/Downloadable_files/fpnb16.pdf

[39] Saleh, N., Taufiq, A., Widodo, Y., Sundari, T., Gusyana, D., Rajagukguk, R.P., Suseno, S.A. (2016). Guidelines for Cultivation of Cassava in Indonesia. IAARD Press, Jakarta. https://balitkabi.litbang.pertanian.go.id/wpcontent/uploads/2017/03/mono-pedoman-budidayaubikayu-cover-dalam.pdf.

[40] Mutiara, C., Bolly, Y.Y. (2019). Identification of agricultural activities and soil fertility in the cultivation area of Nuabosi cassava. Caraka Tani J. Sustain. Agric., 34(1): 22-30.

[41] Rezaei, H., Jafarzadeh, A.A., Alijanpour, A., Shahbazi, F., Kamran, K.V. (2015). Effect of slope position on soil properties and types along an elevation gradient of arasbaran forest, Iran. Int. J. Adv. Sci. Eng. Inf. Technol., 5(6): 449-456. https://doi.org/10.18517/ijaseit.5.6.589

[42] Everest, T., Sungur, A., Özcan, H. (2020). Determination of agricultural land suitability with a multiple-criteria decision-making method in Northwestern Turkey. Int. J. Environ. Sci. Technol., no. 0123456789. https://doi.org/10.1007/s13762-020-02869-9

[43] Wicaksono, H., Putra, E.T.S., Muhartini, S. (2015). Suitability of Canna (Canna indica L.), Stink Lily (Amorphophallus paeoniifolius (Dennst.) Nicolson), and Cassava (Manihot esculenta Crantz) under Menoreh Hills Agroforestry. Vegetalika, 4(1): 87-101. https://doi.org/10.22146/veg.6426

[44] Banuwa, I.S. (2013). Erosion. First Edition. Kencana Prenada Media Grup. Jakarta.

[45] Fageria, N.K. (2012). Role of soil organic matter in maintaining sustainability of cropping systems. Commun. Soil Sci. Plant Anal., 43(16): 2063-2113. https://doi.org/10.1080/00103624.2012.697234

[46] Dewi, W.S., Wahyuningsih, G.I., Syamsiah, J., Mujiyo. (2018). Dynamics of N-NH4+, N-NO3-, and total soil nitrogen in paddy field with azolla and biochar. IOP Conference Series: Earth and Environmental Science, pp. 012014. https://iopscience.iop.org/article/10.1088/1755$1315 / 142 / 1 / 012014$

[47] Suntoro, S., Widijanto, H., Suryono, Syamsiyah, J., Afinda, D.W., Dimasyuri, N.R., Triyas, V. (2018). Effect of cow manure and dolomite on nutrient uptake and growth of corn (Zea mays I.). Bulg. J. Agric. Sci., 24: 1020-1026

[48] Biratu, G.K., Elias, E., Ntawuruhunga, P. (2019). Soil fertility status of cassava felds treated by integrated application of manure and NPK fertilizer in Zambia. 
Environtmental Syst. Res., 8(3): 1-13.

[49] Prasetyo, A., Listyorini, E., Utomo, W.H. (2014).
Pemberian Pupuk Organik Dan Anorganik. J. Tanah dan Sumberd. Lahan, 1(1): 27-37. http://jtsl.ub.ac.id. 